\title{
A synergy effect of internationalization and firm size on performance \\ US hotel industry
}

\author{
Seoki Lee \\ School of Hospitality Management, Pennsylvania State University, \\ University Park, Pennsylvania, USA \\ Arun Upneja \\ School of Hospitality Administration, Boston University, Boston, \\ Massachusetts, USA \\ Özgür Özdemir \\ Department of Hotel Administration, School of Applied Sciences, \\ Özyegin University, Istanbul, Turkey, and \\ Kyung-A Sun \\ Pennsylvania State University, University Park, Pennsylvania, USA
}

Synergy effect

Received 25 September 2012 Revised 2 February 2013

16 March 2013

Accepted 31 March 2013

\begin{abstract}
Purpose - The purpose of the current study is to investigate the existence of a negative synergy effect of internationalization and firm size on firm performance for publicly traded US hotels.

Design/methodology/approach - The study performs the two-way fixed-effects model to investigate the proposed negative synergy effect.

Findings - The findings do not support the proposed negative synergy effect, but support the positive synergy effect of internationalization and firm size on performance.

Originality/value - This study examines the hypothesis developed based on the agency cost theory using the hotel industry's unique monitoring cost argument. However, findings support the opposite, implicitly suggesting that the hotel's monitoring cost in the international franchising context may not be severe as some expect.
\end{abstract}

Keywords Business performance, Business expansion scheme, Hotels, United States of America

Paper type Research paper

\section{Introduction}

As evidenced by the fact that the hotel industry's global revenues exceeded $\$ 300 \mathrm{bn}$ in 2010, investing abroad to expand business, that is, internationalization, has become a widely accepted and adopted strategy for many major US hotel chains (Kwon, 2011). The highly saturated US hotel industry motivates US hotel companies to expand operations internationally to capitalize on benefits from foreign markets, such as increased market share, reduced business risks from diversified operations, and enhanced brand recognition (Baek, 2004; Lu and Beamish, 2004; Thomas and Eden,

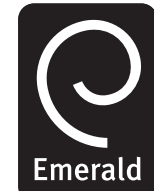

Emerald

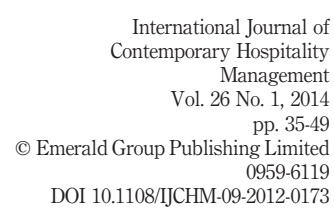


IJCHM

26,1

36
2004). Despite the apparent positives, the bottom line of any strategy should relate to a company's performance (Hitt et al., 2006).

In terms of effects of internationalization on a firm's performance, two distinct groups of thought argue opposite effects, i.e. the positive and negative effects of internationalization. One group of researchers suggested a positive effect from internationalization on a firm's performance based on several theoretical or logical underpinnings, such as the resource-based view, organizational learning prospects, and the flexibility perspective (e.g. Baek, 2004; Lu and Beamish, 2004; Thomas and Eden, 2004). On the other hand, supporters of the agency cost theory argued that as firms expand their operations to foreign countries, agency costs tend to increase because monitoring managers in foreign countries with complex organizational structures becomes more difficult and costly (Saudagaran, 2002).

However, the effect of internationalization may not be limited to being linear or independent of other factors. Although more simplistic arguments can certainly aid understanding the phenomenon better and are useful as a broad basis, more recent internationalization literature suggested that the relationship between internationalization and firm performance is more complex (Lee et al., 2010), and the hospitality literature has acknowledged and incorporated that issue into investigations (Lee, 2008; Tang and Jang, 2010). Coinciding with the complexity issue, the current study attempts to examine internationalization as an inter-related factor in the link between a firm's important characteristic (i.e. firm size) and performance.

The agency cost theory shows a close relationship between a firm's internationalization and size in terms of their implications on the firm's performance. The theory provides support for a negative effect on firm performance regarding both firm size and internationalization due to the expected increase in costs as a firm grows in size and expands into foreign countries. Considering the common theoretical context, this study proposes that a negative synergy effect occurs when both factors (i.e. firm size and internationalization) simultaneously increase. In other words, an increase in a firm's degree of internationalization will aggravate the magnitude of a potentially negative effect of a firm's growth in size and vice versa on its performance. This negative synergy effect may be uniquely observed in the US hotel industry because monitoring costs in the foreign franchising context may become increasingly significant due to wide dispersion of operations in a geographical manner.

This study therefore investigates the negative synergy effect of growth in internationalization and firm size for publicly traded US hotel firms during the period 1990-2010. For methodology, the study adopts the two-way fixed-effects model, following suggestions by Greene (2003) and Wooldridge (2002) to test the proposed hypothesis. The findings, however, reveal the opposite - a positive synergy between growth in internationalization and size, possibly suggesting that the expected significant growth in costs to monitor foreign franchisees as a hotel expands abroad may not be as severe as expected. The next section reviews the relevant literature and describes the methodology, including data collection and the model with the study's variables. The results section follows, and the study concludes with discussions and limitations. 


\section{Literature review}

\section{Costs and benefits of internationalization}

Synergy effect

Internationalization is risky (Caves, 1996), yet expanding into global markets provides domestic firms with significant benefits; enhanced firm value is an alleged benefit. Imperfect capital market theory suggests that international firms can provide more diversified portfolios to their shareholders and by doing so improve the firm's value (Doukas and Travlos, 1988; Mikhail and Shawky, 1979). From this standpoint, internationalization is a value-adding strategy, a view supported by Lu and Beamish (2004) because internationalization increases a firm's flexibility. "Exploration" and "exploitation" of new resources and environments from foreign markets can create "flexibility", which enables the firm to adjust, necessarily and adequately, to market changes. Other researchers, such as Baek (2004), Thomas and Eden (2004), shared the view that internationalization provides a firm with operational flexibility and additional resources that enhances competitive positioning. In the same vein, Bartlett et al. (2008) concluded that multinational involvement enables firms to have access to more efficient sources and process technologies. Considering all these factors, an emerging fact is that international expansion allows firms to benefit from economies of scale from resources obtained from international markets (Kogut, 1985).

The organizational learning theory also provides evidence of positive aspects of expanding business into foreign markets. Based on the theory, firms can gain knowledge and experience from foreign markets, and although initial costs of such learning may be significant (perhaps creating a negative slope for the initial stage of internationalization in relation to firm value or performance), at a later stage, firms can apply the knowledge and experience accumulated from their foreign subsidiaries to improve products, services, and processes (Kobrin, 1991; Thomas, 2006; Zahra et al., 2000). Additional advantages of international expansion are that multinational corporations gain perspectives for global competition, markets, and other business opportunities (Contractor et al., 2003).

Contrary to the support mentioned earlier for the effects of internationalization, agency cost theory argues for a negative effect from internationalization on firm performance and value. Since a discrepancy in interests exists between principals (i.e. owners) and agents (i.e. managers), costs (i.e. agency costs) occur when owners monitor managers to ensure that managers' activities align with owners' interests. When a discrepancy exists, managers may not place a priority on maximizing owners' value, but rather seek their own benefits (Brealey and Myers, 2003). When applying the agency theory to the internationalization issue, the theory supports a negative effect from internationalization because business expansion typically creates more complex systems, thereby increasing monitoring costs (Eun et al., 1996; Saudagaran, 2002). Furthermore, operating internationally raises uncertainties a firm needs to address (Boyd and Fulk, 1996), increases complexities (Sanders and Carpenter, 1998), and multiplies regulatory compliance requirements (Roblyn, 2001). Without effective management, increased uncertainty may consequently lead to operational and financial failures.

\section{International expansion and firm performance}

Hitt et al. (2006) argued that the primary purpose of a strategy must be to increase a firm's value, by interpolation, and internationalization, as a significant corporate 
IJCHM

26,1

38 strategy, must accomplish that end. If the advantages of international expansion discussed in the previous section outweigh its costs, then internationalization should be a value-adding strategy and ultimately affect the bottom-line performance of a company. Other researchers, such as Tallman and Li (1996), shared the value-adding perspective by arguing that international diversification generally improves a firm's operational performance. Several proposals elucidate relationship patterns between internationalization and firm performance, and among them, linear and curvilinear patterns are the primary avenues of research. A significant number of researchers argued that the relationship between internationalization and firm performance is mainly curvilinear, represented by an inverted U-shape (Hitt et al., 1997; Gomes and Ramaswamy, 1999). Perhaps, one of the best demonstrations of this U-shape relationship is the study of $\mathrm{Lu}$ and Beamish (2004), who examined the degree of internationalization of a large sample of Japanese industrial firms for a 12-year period and reported that, in the early stages of internationalization, firm performance positively related to the degree of internationalization. However, as firms' degrees of internationalization increased, performances tended to decline as centralized control became a substantial problem in international operations. Kogut (1985), Porter (1985), and Contractor (2002) included a squared term in their models to account for the curvilinear nature of the effect of internationalization on firm performance. Others, on the other hand, proposed a linear relationship and documented both positive (Grant, 1987; Morck and Yeung, 1991; Tallman and Li, 1996) and negative (Siddharthan and Lall, 1982; Geringer et al., 2000) relationships between internationalization and firm performance.

For the hotel industry, many studies examined several international issues including brand expansion (Dev et al., 2007), franchising and management contracts (Dev et al., 2002), ownership and control of assets (Dunning and McQueen, 1982), international buyer-seller relationships (Jones and McCleary, 2004), and so on. Despite the focus of these studies, effect of internationalization on firm performance has gained little attention. Lee (2008) and Tang and Jang (2010), as rare hospitality studies, attempted to explore such issue. Lee (2008) examined effects of internationalization on firm performance for publicly traded US hotels and found a curvilinear relationship (i.e. U-shaped relationship), which Tang and Jang (2010) confirmed, but they failed to support another hypothesis of the moderating effect of internationalization on the link between advertising expenditure and firm performance.

\section{Hypothesis development}

The literature recognized firm size as an important characteristic that significantly influences firm performance (Bers and Springer, 1997). According to the economies of scale argument, as a firm grows larger, benefits (e.g. personnel specialization, common governance, and decreasing production cost per unit) tend to outweigh costs (e.g. inefficiencies of operations and management) from increased size, resulting in lowering average costs per production unit (Ambrose et al., 2005; Dunning, 1989). Contrarily, other researchers argued that costs can outweigh benefits, proposing diseconomies of scale (Canback et al., 2006; Diaz and Sanchez, 2008) based on the agency cost theory (Jensen, 1986, 2000). Furthermore, as discussed in the literature review section, the agency cost theory also plays a major role in supporting the negative effect of internationalization on firm performance. Thus, the current study 
proposes that this theoretical underpinning inter-relates internationalization with the size effect on firm performance.

According to the agency cost theory, monitoring costs increase not only from a firm's increasing size, but also from a firm's increasing involvement in international operations. Considering this negative effect of both situations, when firm size and internationalization increase, simultaneously, a synergistic effect can be expected, suggesting that internationalization can magnify the negative effect of the increased firm size, and vice versa, on performance. This explanation proposes a negative synergy effect of internationalization and firm size. Moreover, the proposed synergy effect may be more pronounced in the hotel industry where widely practiced franchising strategies, which could be an expansion strategy domestically and internationally, manifests a unique monitoring cost, which occurs because franchisors strive to maintain set, standardized services, consistent throughout franchisees' operations. However, often, franchisees, to maximize their self-interests, to the detriment of franchisors, choose to adopt individualized operating strategies, which do not comply with franchisors' standards (Andrew et al., 2007). Therefore, based on the agency cost theory regarding both size and internationalization's effects coupled with the specific hotel industry's monitoring cost issue, this study develops the hypothesis.

H1. There is a negative synergistic effect from growth in internationalization and firm size on firm performance.

\section{Methodology \\ Data}

The study retrieved required data from four sources: Compustat, for sampled hotels' financial data, such as total assets, total revenue, number of outstanding shares, and net income, and companies' annual reports (10Ks) for international operations information. For the internationalization variable (DOI), this study collected number of total hotel properties and number of hotel properties operated in foreign countries. This study also collected two additional data items: number of hotel rooms from $10 \mathrm{Ks}$ and foreign income before tax from Compustat. However, the both samples were more limited than the hotel property data. Therefore, the main analysis uses the hotel property data to measure DOI.

After the initial data collection, the study performed a screening process and excluded those companies whose main operations lie outside the hotel context. The study also excluded non-US based companies because differing external factors may impact those companies' operations and outcomes. Home Inns \& Hotels Management, a China-based company, and Sun Resorts Ltd, a Republic of Mauritius-based company, are examples of these exclusions. Orient-Express Hotels Ltd (which operates multiple businesses, such as deluxe hotels, restaurants, tourist trains, and river/canal cruises) and Maui Land \& Pineapple Company, Inc. (which operates in three industry segments, i.e. agriculture, resorts, and community developments) are examples of exclusion of businesses whose primary interests are outside hospitality. Finally, the study identified outliers based on standardized residual values. The study performed the main regression analysis, estimated standardized residuals, and eliminated firm observations if the associated studentized residuals exceeded absolute values of 4 (Younger, 1979). Through this process, the study identified three observations as 
IJCHM

26,1

40 outliers, and thus eliminated them from the data. The final sample size for the main analysis is 279 and the sample period spans from 1990 to 2010.

\section{Dependent variable}

This study measures a firm's value performance, the dependent variable, by Tobin's $Q$. In particular, the study uses approximate $q(Q)$, following Chung and Pruitt (1994). Calculation of $Q$ is: (MVE + PS + DEBT)/TA, where MVE is the product of a firm's stock price and the number of common shares outstanding, PS represents the liquidating value of outstanding preferred shares, DEBT is the value of short-term liabilities, net of short-term assets plus the book value of long-term assets, and TA represents the book value of total assets. The study chose Tobin's $Q$ over other performance measures, especially stock returns and accounting profitability measures (e.g. return on assets or return on equity) because of the ex ante nature of Tobin's $Q$ (Lang and Stulz, 1994). Stock growth rates and accounting profitability are ex post measures, reflecting a firm's performance over a certain historical period; many potential confounding factors affect those measures, while Tobin's $Q$ is an unbiased estimate of the firm's value including future prospects (Jose et al., 1986; Wernerfelt and Montgomery, 1988; Lang and Stulz, 1994), assuming the efficient market hypothesis (Fama, 1965). This study log-transforms Tobin's $Q$ to alleviate potential normality violation.

\section{Main variables}

This study examines three main factors:

(1) internationalization;

(2) firm size; and

(3) an interaction term for the two.

First, to measure degree of internationalization (DOI), the study scales the number of hotel properties operated in foreign countries by the number of total properties operated in both domestic and foreign countries. Second, this study measures firm size (SIZE) by the log of total revenues adjusted for the consumer price index (CPI). To avoid negative values after the logarithmic transformation, the study adds 1 to the CPI-adjusted total revenue values for all data points before the transformation. Although the general financial economics literature often uses total assets as proxy for firm size, revenues may be a better representation of a hotel's size than total assets because total assets tend to reflect, incorrectly, sizes of heavily franchised hotels. This study, with support from previous hospitality financial studies, uses revenues as proxy for hotels' or restaurants' sizes (e.g. Lee and Park, 2009; Lee and Xiao, 2011; Koh et al., 2009). Last, the study creates an interaction term of DOI and SIZE (DOI × SIZE) to test the current study's hypothesis (i.e. a negative synergy effect) and the expectation is that the coefficient of DOI $\times$ SIZE is negative.

\section{Control variables}

The models include two control variables:

(1) a firm's profitability; and

(2) leverage. 
The study includes a firm's profitability in the models to control for any confounding effects that profitability has on the relationship between main factors and a firm's value performance $(Q)$. With the common assumption that profitability positively correlates with a firm's value performance (Cho and Pucik, 2005), this study expects a positive coefficient for the variable. The measurement for profitability, in this study, is return on assets (ROA), calculated by dividing net income by total assets. The study includes a firm's leverage ratio in the model to control for a firm's capital structure because the literature suggests a significant effect of a firm's capital structure on value performance. Mixed results and arguments exist regarding effects of capital structure on a firm's performance. Positive effects may exist due to tax benefits from increasing a firm's debt level, while negative effects may arise from financial markets' tendency to perceive highly leveraged firms to be risky, and consequently, incur expectedly high costs of capital (McConnell and Servaes, 1990). Therefore, this study does not have a directional expectation for leverage (LEV), measured by scaling total liabilities by total assets.

\section{Models}

This study performs a two-way fixed-effects model (by firm and year) to robustly estimate coefficients that may be potentially biased due to unobserved effects in a panel data set. Without controlling for the unobserved effects, estimated coefficients in a panel data set are often biased (Greene, 2003; Wooldridge, 2002). The study chose Fixed-effects model over Random-effects model based on Hausman Test results; the result statistic is 35.75 with p-value less than 0.001 that reject the null hypothesis that the unobserved effects are uncorrelated with the other regressors in the model. If the null hypothesis is rejected, a fixed-effects model produces biased estimators, so a fixed-effects model is preferred (Greene, 2003). The models to test the hypothesis in two different settings are:

$$
Q_{t}=\alpha_{0}+\alpha_{1} \mathrm{DOI}_{t}+\alpha_{2} \mathrm{SIZE}_{t}+\alpha_{3} \mathrm{DOI} \times \mathrm{SIZE}_{t}+\alpha_{4} \mathrm{ROA}_{t}+\alpha_{5} \mathrm{LEV}_{t}+u_{t},
$$

where $Q$ represents a firm's value performance, measured by log of Tobin's $Q$; DOI represents a firm's degree of internationalization, measured by dividing the number of foreign hotel properties by the total number of hotel properties; SIZE represents a firm's size, measured by log of total revenues adjusted for consumer price index (CPI); $\mathrm{DOI} \times$ SIZE represents an interaction term of DOI and SIZE; ROA represents return on assets, measured by net income scaled by total assets; LEV represents a firm's financial leverage, measured by total liabilities scaled by total assets; $u$ represents error terms, and there are 37 firm dummy variables and 20 year dummy variables included in the analysis, but these are not presented in the model due to space limitations.

\section{Results}

Descriptive statistics

The study first performed a descriptive analysis, and Table I presents a summary of the results. Tobin's $Q(Q)$ ranges from 0.052 to 11.751 with a mean value of 1.563 , meaning that the market value of publicly traded US hotels is, on average, 1.5 times greater than their replacement costs. Degree of internationalization (DOI) ranges from 0 percent to 81 percent with the mean value of 7.8 percent. These statistics clearly include both domestic and international firms. When the study includes only international hotels (i.e. Choice, Four Seasons, Hyatt, InterContinental, Marriott, and Starwood) that provided property 


\section{IJCHM \\ 26,1}

\begin{tabular}{lccccc}
\hline Variable & $n$ & Mean & SD & Minimum & Maximum \\
\hline$Q$ & 279 & 1.563 & 1.459 & 0.052 & 11.751 \\
DOI & 279 & 0.078 & 0.164 & 0 & 0.81 \\
ROA & 279 & 0.030 & 0.107 & -0.329 & 0.372 \\
Revenue (\$US, millions) & 279 & 1,376 & 2,742 & 1 & 12,990 \\
Net income (\$US, millions) & 279 & 75 & 196 & -741 & 1,255 \\
Total assets (\$US, millions) & 279 & 2,121 & 3,403 & 1 & 16,481 \\
Leverage & 279 & 0.626 & 0.258 & 0.006 & 1.774
\end{tabular}

Table I.

Summary of descriptive statistics
Notes: $Q$ represents a firm's value performance, measured by Tobin's $Q$; DOI represents a firm's degree of internationalization, measured by dividing the number of hotel properties operated in foreign countries by the number of total hotel properties; ROA represents return on assets, measured by net income scaled by total assets, and leverage represents a firm's financial leverage, measured by total liabilities scaled by total assets

data for internationally operated hotels, DOI values range from 5 percent to 81 percent with a mean value of 32 percent. ROA shows a mean value of 0.030 with a minimum (maximum) value of -0.857 (0.372). The sampled companies had revenues of $\$ 1,376 \mathrm{~m}$ and net income of $\$ 75 \mathrm{~m}$, on average, during the period 1990 to 2010, and held average total assets of $\$ 2,121 \mathrm{~m}$ during the same period. Leverage, measured by debt-to-asset ratio, ranged from 0.006 to 1.774 with a mean value of 0.626 .

Next, the study performed a Pearson's correlation analysis, and the findings appear in Table II. According to the findings, Tobin's $Q(Q)$ positively correlates with all five independent variables: DOI $(r=0.383)$, SIZE $(r=0.152)$, DOI $\times$ SIZE $(r=0.322)$, ROA $(r=0.246)$, and LEV $(r=0.364)$. For DOI, a positive, significant correlation exists with SIZE $(r=0.376)$, DOI $\times$ SIZE $(r=0.978)$ and ROA $(r=0.141)$, but an insignificant correlation with LEV $(r=0.017)$. The high correlation between DOI and DOI $\times$ SIZE is alarming as a potential cause of multicollinearity problem. Thus, this study created a new estimated variable for DOI $\times$ SIZE (including DOI and SIZE) using the mean-centering approach (Tabachnick and Fidell, 1996), and ran the correlation analysis again; the correlation between centered values of $Q$ and DOI $\times$ SIZE becomes -0.0440 , which is very insignificant[1].

\begin{tabular}{lccccc}
\hline Variable & DOI & SIZE & DOI $\times$ SIZE & ROA & \multicolumn{1}{c}{ LEV } \\
\hline$Q$ & $0.383^{* * *}$ & $0.152^{* *}$ & $0.322^{* * *}$ & $0.246^{* * *}$ & $0.364^{* * * *}$ \\
DOI & & $0.376^{* * *}$ & $0.978^{* * *}$ & $0.141^{* *}$ & 0.017 \\
SIZE & & $0.440^{* * *}$ & $0.121^{* *}$ & $0.207^{* *}$ \\
DOI $\times$ SIZE & & & & $0.134^{*}$ & 0.018 \\
ROA & & & & & 0.033
\end{tabular}

Notes: $Q$ represents a firm's value performance, measured by log of Tobin's $Q$; DOI represents a firm's degree of internationalization, measured by dividing the number of hotel properties operated in foreign countries by the number of total hotel properties; SIZE represents a firm's size, measured by the log of total revenues adjusted for consumer price index $(\mathrm{CPI})$; DOI $\times$ SIZE represents an interaction

Table II.

Summary of Pearson's correlation term of SIZE and DOI; ROA represents return on assets, measured by net income scaled by total assets; LEV represents a firm's financial leverage, measured by total liabilities scaled by total assets: $* * *$ and $* * *$ represent significance levels of $0.05,0.01$ and $<0.0001$, respectively 
IJCHM

26,1

44

\section{Discussion}

The main purpose of this study is to investigate a negative synergistic effect of internationalization and firm size on firm performance for publicly traded US hotels. To examine this proposal, the study used the data from 1990 to 2010 and conducted two-way fixed-effects model. The interaction term $(\mathrm{DOI} \times \mathrm{SIZE})$ was specifically tested for the synergy effect, and findings of the current study suggest a positive synergistic effect, failing to support the hypothesis. In addition, the study revealed that internationalization has a positive main effect on firm performance while firm size has a negative main effect on firm performance.

Based on the results of this study, publicly traded US hotels may benefit from expanding into international operations when attempting to grow in size. This finding is against the argument that the franchising strategy negates the performance of international hotels compared to domestic hotels as they grow in size, due to more sharply increasing costs to monitor international franchisees' compliance with franchisors' service quality standards than monitoring domestic franchisees' compliance. Combined with the findings on main effects of both internationalization (i.e. positive) and firm size (i.e. negative) on firm performance, the positive synergy effect may suggest that an expansion into foreign countries alleviates negative effects from growth in firm size. These findings may support the theoretical arguments of the resource-based view, organizational learning prospects, and flexibility perspective (Baek, 2004; Lu and Beamish, 2004; Thomas and Eden, 2004).

An interesting argument may arise for the hotel industry from the franchising strategy in relation to the agency cost theory. With the franchising strategy, international hotels may reduce their agency costs, in general, because franchisees are typically local to the foreign site. This factor decreases a firm's risks for operating units in foreign countries and in addition, franchisees may be self-motivated to generate profits. These findings are highly industry-specific, making contributions to the hotel financial economics literature. Lee (2008) examined effects of internationalization in the US hotel industry using only international hotels, excluding domestic hotels, and thus could not suggest the effect from hotels' entering foreign markets. Also, although Tang and Jang (2010) provided evidence of better performance by international hotels than domestic hotels, their findings are based on a univariate test (i.e. $t$-test) without controlling for other potential confounding factors (e.g. firm size, leverage, profitability, and so on). Compared to Tang and Jang (2010), the current study performed two-way fixed-effects model to account for a typical problem embedded in panel data, the unobserved effects. Therefore, the current study's contributions to the hospitality literature from examining both international and domestic hotels, and using a more advanced methodology become evident.

Although with a reasonable sample size of 279 , the sample of international hotels is still somewhat limited. In an attempt to increase the sample of the internationalization data, this study retrieved foreign income-before-tax data from Compustat and also collected the number of hotel rooms in foreign markets from $10 \mathrm{Ks}$. However, due to even more limited data than the international property data used in the main analysis of this study, these two approaches proved unsuccessful. There is another methodological issue about controlling for macro-economic factors. Notably, the current study's adoption of the two-way (by both firm and year) fixed-effects model 
controls for all potential macro-economic factors such as foreign exchange rates or GDP. It is because those macro-economic factors are invariant across firms in a given year (Greene, 2003).

While consideration of many other factors for making such decision is imperative, this study's findings may assist their decision-making processes with empirical evidence specifically for the hotel industry. Findings on the synergy effect may suggest that hotel executives and owners should consider expanding into foreign operations, if they want to grow further in size, rather than growing domestically, whenever possible. This strategy should be surely dependent on each firm's experiences with international operations and capabilities to do so. Without sufficient experiences or resources for an international expansion, hotel firms may not or should not pursue increasing their international presence. However, even when a hotel firm does not have experiences with international operations, the managers and owners may want to give it a serious consideration because an expansion into a domestic market for a growth strategy may negatively affect hotels' performance. Furthermore, investors holding the hotel portfolio may benefit from the findings of this study. They may use the information about a hotel firm's internationalization status or the firm's plan to enter into foreign countries along with other decision-supporting factors for their hotel investment portfolio. However, a caution should be exercised because the current findings do not directly measure or examine the effect of the internationalization strategy on the investment portfolio.

\section{Limitations and suggested future research}

This study is not free from limitations. First, the study's findings should be cautiously applied in other contexts, such as the private hotel sector or non-US environments. An application of the current method to those other settings may enhance external validity of this study's findings, and consequently, encourage future research in those contexts. Second, other inter-related factors (e.g. franchising strategy, revenue management adoptions, various types of diversifications, and innovation levels) may impact the relationship between internationalization and firm size; the complexity of these factors requires further inquiry. Especially, when considering that the franchising may exert a critical role in relation to the internationalization, further research should be encouraged to incorporate the franchising strategy into the analysis. Third, the measurement of degree of internationalization (DOI) may have some issues. For example, the same 50 percent DOI for two hotels may present different things if one hotel has two total units and one foreign unit while the other hotel has 200 total units and 100 foreign units. However, in such manner, some other typical DOI measures will not work either, such as a proportion of foreign revenues or income to total revenues or income. Therefore, following some previous hospitality literature (e.g. Koh et al., 2009; Lee, 2008), this study uses the number of foreign properties to total number of properties. Last, the argument regarding the increased monitoring costs in the international setting may not be well reflected in the measurement of internationalization. However, due to limited availability of further detailed data, such as international franchised properties, it is not readily feasible to improve on the measurement. Future studies may search for better measures to reflect the issue more accurately.

\section{Synergy effect}


$\mathrm{IJCHM}$

26,1

46

\section{Note}

1. Although the correlation becomes negative and insignificant, there are two issues that should be noted. First, the negative coefficient does not mean much because it is not statistically significant. Second, the insignificant relationship between the two variables becomes significant in the main analysis where other important confounding factors are controlled. This is exactly why a multivariate analysis is preferred over a univariate analysis; the univariate analysis does not account for confounding factors.

\section{References}

Ambrose, B., Highfield, M. and Linneman, P. (2005), "Real estate and economies of scale: the case of REITs", Real Estate Economics, Vol. 33 No. 2, pp. 323-350.

Andrew, W.D., Damitio, J.W. and Schmidgall, R.S. (2007), Financial Management for the Hospitality Industry, Pearson Prentice Hall, Upper Saddle River, NJ.

Baek, H.Y. (2004), "Corporation diversification and performance: evidence on production efficiency”, Journal of Multinational Financial Management, Vol. 14, pp. 135-152.

Bartlett, C., Ghoshal, S. and Beamish, P. (2008), Transnational Management - Text Cases and Readings in Cross Border Management, 5th ed., Irwin McGraw-Hill, Boston, MA.

Bers, M. and Springer, T. (1997), "Economies of scale of real estate", The Journal of Real Estate Research, Vol. 14 No. 3, pp. 275-290.

Boyd, B.K. and Fulk, J. (1996), "Executive scanning and perceived uncertainty: a multidimensional model”, Journal of Management, Vol. 22 No. 1, pp. 1-21.

Brealey, R.A. and Myers, S. (2003), Principles of Corporate Finance, 7th ed., McGraw-Hill, New York, NY.

Canback, S., Samouel, P. and Price, D. (2006), "Do diseconomies of scale impact firm size and performance? A theoretical and empirical over view", Journal of Managerial Economics, Vol. 4 No. 1, pp. 27-70.

Caves, R.E. (1996), Multinational Enterprise and Economic Analysis, 2nd ed., Cambridge University Press, Cambridge.

Cho, H.-J. and Pucik, V. (2005), "Relationship between innovativeness, quality, growth, profitability, and market value", Strategic Management Journal, Vol. 26, pp. 555-575.

Chung, K.H. and Pruitt, S.W. (1994), "A simple approximation of Tobin's q", Financial Management, Vol. 23 No. 3, pp. 70-74.

Contractor, F.J. (2002), "International expansion strategies", International Encyclopedia of Business and Management, International Thomson Business Press, London.

Contractor, F.J., Kundu, S.K. and Hsu, C. (2003), "A three-stage theory of international expansion: the link between multinationality and performance in the service sector", Business Studies, Vol. 34 No. 1, pp. 5-18.

Dev, C.S., Erramilli, M.K. and Agarwal, S. (2002), "Brands across borders: determining factors in choosing franchising or management contracts for entering international markets", Cornell Hotel and Restaurant Administration Quarterly, Vol. 43 No. 6, pp. 91-104.

Dev, C., Brown, J. and Zhou, K.Z. (2007), “Global brand expansion: how to select a market entry strategy”, Cornell Hospitality Quarterly, Vol. 48 No. 1, pp. 13-27.

Diaz, M. and Sanchez, R. (2008), "Firm size and productivity in Spain: a stochastic frontier analysis”, Small Business Economics, Vol. 30 No. 3, pp. 315-323. 
Doukas, J. and Travlos, N. (1988), "The effect of corporate multinationalism on shareholders wealth: evidence from international acquisitions", Journal of Finance, Vol. 43, pp. 1161-1175.

Dunning, J.H. (1989), "Transnational corporations and the growth of service: some conceptual and theoretical issues", UNCTC Studies Series A No. 9, United Nations, New York, NY.

Dunning, J.H. and McQueen, M. (1982), "Multinational corporations in the international hotel industry", Annals of Tourism Research, Vol. 9, pp. 69-90.

Eun, C., Kolodny, R. and Scherega, C. (1996), "Cross-border acquisitions and shareholder wealth: tests of the synergy and internationalization hypotheses", Journal of Banking and Finance, Vol. 20, pp. 1559-1582.

Fama, E.F. (1965), "Fixed walks in stock market prices", Financial Analysts Journal, Vol. 21 No. 5, pp. 55-59.

Geringer, J.M., Tallman, S. and Olsen, D.M. (2000), "Product and international diversification among Japanese multinational firms”, Strategic Management Journal, Vol. 21 No. 1, pp. 51-80.

Gomes, L. and Ramaswamy, K. (1999), "An empirical examination of the form of relationship between multinationality and performance", Journal of International Business Studies, Vol. 30 No. 1, pp. 173-188.

Grant, R.M. (1987), "Multinationality and performance among British manufacturing companies", Journal of International Business Studies, Vol. 18 No. 3, pp. 79-89.

Greene, W.H. (2003), Econometric Analysis, 5th ed., Pearson Education, Upper Saddle River, NJ.

Hair, J.F., Anderson, R.E., Tatham, R.L. and Black, W.C. (1998), Multivariate Data Analysis, 5th ed., Pearson Education, Upper Saddle River, NJ.

Hitt, M.A., Hoskisson, R.E. and Kim, H. (1997), "International diversification: effects on innovation and firm performance in product-diversified firms", Academy of Management Journal, Vol. 4, pp. 767-798.

Hitt, M.A., Bierman, L., Uhlenbruck, K. and Shimizu, K. (2006), "The importance of resources in the internationalization of professional services firms: the good, the bad, and the ugly", Academy of Management Journal, Vol. 49 No. 6, pp. 1137-1157.

Jensen, M.C. (1986), “Agency costs of free cash flow, corporate finance, and takeovers”, American Economic Review, Vol. 76 No. 2, pp. 323-329.

Jensen, M.C. (2000), A Theory of the Firm: Governance, Residual Claims, and Organizational Forms, Harvard University Press, Cambridge, MA.

Jones, D.L. and McCleary, K.W. (2004), "A model for assessing cultural impacts on international buyer-seller relationships for key accounts of hotel companies”, Journal of Hospitality and Tourism Research, Vol. 28 No. 4, pp. 425-443.

Jose, M.L., Nichols, L.M. and Stevens, J.L. (1986), "Contribution of diversification, promotion, and R\&D to the value of multiproduct firms: a Tobin's $q$ approach”, Financial Management, Vol. 15 No. 4, pp. 33-42.

Kobrin, S.J. (1991), "An empirical analysis of the determinants of global integration”, Strategic Management Journal, Vol. 12 No. 1, pp. 17-37.

Kogut, B. (1985), "Designing global strategies: profiting from operational flexibility", Sloan Management Review, Vol. 26, pp. 27-38. 
IJCHM

26,1
Koh, Y., Lee, S. and Boo, S.Y. (2009), "Impact of brand recognition and brand reputation on firm performance: US based multinational restaurant companies' perspective”, International Journal of Hospitality Management, Vol. 28 No. 4, pp. 620-630.

Kwon, E.Y. (2011), Industry Surveys: Lodging \& Gaming, Standard \& Poor's, New York, NY.

Lang, L.H.P. and Stulz, R.M. (1994), "Tobin's q, corporate diversification, and firm performance", Journal of Political Economy, Vol. 102 No. 6, pp. 1248-1280.

Lee, S. (2008), "Internationalization of US multinational hotel companies: expansion to Asia versus Europe", International Journal of Hospitality Management, Vol. 27 No. 4, pp. 657-664.

Lee, S. and Park, S.Y. (2009), "Do socially responsible activities help hotels and casinos achieve their financial goals?”, International Journal of Hospitality Management, Vol. 28 No. 1, pp. 105-112.

Lee, S. and Xiao, Q. (2011), "Effects of capital intensity on firm performance for publicly traded US hotels and restaurants: a linear or curvilinear relationship?", International Journal of Contemporary Hospitality Management, Vol. 23 No. 6, pp. 862-880.

Lee, T., Chan, K.C., Yeh, J.-H. and Chan, H.-Y. (2010), “The impact of internationalization on firm performance: a quantile regression analysis", International Review of Accounting, Banking and Finance, Vol. 2 No. 4, pp. 39-59.

Lu, J. and Beamish, P.W. (2004), "International diversification and firm performance: the S-curve hypothesis”, Academy of Management Journal, Vol. 47 No. 4, pp. 598-609.

McConnell, J.J. and Servaes, H. (1990), "Additional evidence on equity ownership and corporate value”, Journal of Financial Economics, Vol. 27 No. 2, pp. 595-612.

Mikhail, A. and Shawky, H. (1979), "Investment performance of US-based multinational corporations", Journal of International Business Studies, Vol. 10 No. 1, pp. 54-66.

Morck, R. and Yeung, B. (1991), "Why investors value multinationality", Journal of Business, Vol. 64 No. 2, pp. 165-178.

Porter, M.E. (1985), Competitive Advantage: Creating and Sustaining Superior Performance, The Free Press, New York, NY.

Roblyn, S. (2001), "Top team characteristics and the business strategies of Japanese firms", Corporate Governance, Vol. 1 No. 2, pp. 4-13.

Sanders, G. and Carpenter, M.A. (1998), "Internationalization and firm governance: the roles of CEO compensation, top team composition, and board structure", Academy of Management Journal, Vol. 41 No. 2, pp. 158-178.

Saudagaran, S.M. (2002), "A review of the literature on the market valuation of multinational firms”, Managerial Finance, Vol. 28 No. 3, pp. 5-18.

Siddharthan, N.S. and Lall, S. (1982), "The recent growth of the largest US multinationals", Oxford Bulletin of Economics and Statistics, Vol. 44 No. 1, pp. 1-13.

Tabachnick, B.G. and Fidell, L.S. (1996), Using Multivariate Statistics, HarperCollins, New York, NY.

Tallman, S. and Li, J. (1996), "Effects of international diversity and product diversity on the performance of multinational firms", Academy of Management Journal, Vol. 39 No. 1, pp. 179-196.

Tang, C.-H. and Jang, S. (2010), "Does international diversification discount exist in the hotel industry?", Journal of Hospitality and Tourism Research, Vol. 34 No. 2, pp. 225-246. 
Thomas, D.E. (2006), "International diversification and firm performance in Mexican firms: a curvilinear relationship?", Journal of Business Research, Vol. 59 No. 4, pp. 501-507.

\section{Synergy effect}

Thomas, D. and Eden, L. (2004), "What is the shape of the multinationality-performance relationship?", Multinational Business Review, Vol. 12 No. 1, pp. 89-110.

Wernerfelt, B. and Montgomery, C.A. (1988), "Tobin's $q$ and the importance of focus in firm Performance", The American Economic Review, Vol. 78 No. 1, pp. 246-250.

Wooldridge, J.M. (2002), Econometric Analysis of Cross Section and Panel Data, The MIT Press, London.

Younger, M.S. (1979), A Handbook for Linear Regression, Duxbury Press, North Scituate, MA.

Zahra, S.A., Ireland, R.D. and Hitt, M.A. (2000), "International expansion by new venture firms: international diversity, mode of market entry, technological learning, and performance", Academy of Management Journal, Vol. 43 No. 5, pp. 925-950.

\section{Corresponding author}

Seoki Lee can be contacted at: leeseoki@psu.edu

To purchase reprints of this article please e-mail: reprints@emeraldinsight.com Or visit our web site for further details: www.emeraldinsight.com/reprints 